\title{
PENGARUH PERUBAHAN LINGKUNGAN TERHADAP STOK KARBON PADA EKOSISTEM LAMUN DI PULAU-PULAU KECIL, STUDI KASUS: GUGUSAN KEPULAUAN SERIBU
}

\section{THE INFLUENCE OF ENVIRONMENTAL CHANGES ON CARBONSTOCK IN SEAGRASS ECOSYSTEM IN SMALL ISLANDS, STUDY CASE: THOUSAND ISLANDS ARCHIPELAGO}

\author{
Agustin Rustam, Yusmiana Puspitaningsih Rahayu, Devi Dwiyanti Suryono, Hadiwijaya Lesmana Salim, August \\ Daulat, \& Mariska A. Kusumaningtyas
}

Pusat Riset Kelautan, Badan Riset dan Sumber Daya Manusia Kelautan dan Perikanan, Kementerian Kelautan \& Perikanan, Republik Indonesia

e-mail : agustin.rustam@kkp.go.id

Diterima tanggal: 22 Juni 2020 ; diterima setelah perbaikan: 06 Desember 2021 ; Disetujui tanggal: 06 Desember 2021

\begin{abstract}
ABSTRAK
Ekosistem lamun merupakan salah satu ekosistem pesisir karbon biru, yang mampu memanfaatkan $\mathrm{CO}_{2}$ dan menyimpannya dalam bentuk karbon organik pada biomassa dan sedimen yang dipengaruhi oleh lingkungannya. Penelitian ini dilakukan pada Maret dan Oktober 2014 di perairan pulau-pulau kecil Kepulauan Seribu, DKI Jakarta. Tujuan penelitian ini mendapatkan stok karbon pada ekosistem lamun berdasarkan perubahan lingkungan, serta pengaruhnya terhadap perubahan iklim. Metode penelitian menggunakan teknik pengambilan sampel dengan cara disengaja mewakili seluruh lokasi penelitian yang terbagi menjadi tiga zona berdasarkan pengaruh lingkungannya, kemudian menganalisis besaran kandungan karbon pada biomassa dan sedimen dari tiap zona lingkungan. Hasil penelitian menunjukan lamun jenis Enhalus acoroides di Pulau Burung (Zona A) memiliki nilai karbon tertinggi dari tujuh jenis lamun yang ditemukan dengan 2,58 MgC/ha, sedangkan total biomassa lamun tertinggi adalah di Pulau Panggang (Zona B) sebesar 4,39 MgC/ha dan terendah di Pulau Kotok Besar (Zona C) dengan 0,56 MgC/ha. Nilai rata-rata biomassa karbon lamun sebesar 1,81 $\pm 0,32 \mathrm{MgC} /$ ha dengan komposisi terbesar di bagian bawah permukaan sebesar $75 \%$ dari total karbon biomassa. Total stok karbon dalam sedimen ekosistem lamun berkisar antara 751,2 - 1.490,4 MgC/ha sampai kedalaman satu meter. Pengaruh lingkungan berdasarkan zona lokasinya menunjukkan bahwa besaran nilai stok karbon semakin tinggi mengarah ke daratan, dengan jumlah jenis lamun yang lebih sedikit dibandingkan dengan zona yang jauh dari pengaruh daratan.
\end{abstract}

Kata Kunci : Lamun, pulau-pulau kecil Kepulauan Seribu, karbon biru, lingkungan.

\section{ABSTRACT}

Seagrass ecosystems are blue carbon coastal ecosystems, that can utilize and store $\mathrm{CO}_{2}$ in the form of organic carbon in biomass and sediments that are influenced by the environment. This research was conducted in March and October 2014 in the Thousand Islands waters, DKI Jakarta, and aimed to obtain carbon stocks in seagrass ecosystems based on environmental changes, and their effects on climate change. The research method uses purposive sampling techniques representing all research locations divided into three location zones based on their environmental influences, then analyzes the amount of carbon content in biomass and sediments from each environmental zone. The results showed that seagrass species Enhalus acoroides on Burung Island had the highest carbon content of seven seagrass species found with $2.58 \mathrm{MgC/ha}$, while the highest total seagrass biomass was on Panggang Island of 4, $39 \mathrm{MgC/ha}$ and the lowest on Kotok Besar Island with 0.56 MgC/ha. The average value of seagrass biomass is $1.81 \pm 0.32 \mathrm{Mg} \mathrm{C/ha}$, with the most significant composition at the bottom of the surface of $75 \%$ of the total biomass carbon. The total carbon stock in sediments of seagrass ecosystems ranges from 751.2 - $1490.4 \mathrm{MgC/h}$ a to a depth of one meter. The influence of the environment based on the location zone shows that the amount of the carbon stock value is higher towards the land, with a smaller number of seagrass species compared to zones far from land influences.

Keywords: Seagrass, Kepulauan Seribu, blue carbon, environment.

Pengaruh Perubahan Lingkungan Terhadap Stok Karbon Pada Ekosistem Lamun Di Pulau-Pulau Kecil, Studi Kasus: Gugusan Kepulauan Seribu - Agustin Rustam, Yusmiana Puspitaningsih Rahayu, Devi Dwiyanti Suryono, Hadiwijaya Lesmana Salim, August Daulat, \& Mariska A. Kusumaningtyas 197 


\section{PENDAHULUAN}

SLamun adalah satu-satunya tumbuhan sejati (Angiospermae) yang telah beradaptasi di perairan laut (McKenzie et al., 2001; Beer et al., 2002; Gacia et al., 2002; Short, 2006). Lamun tumbuh membentuk hamparan padang lamun yang tersebar baik di perairan tropis maupun subtropis (Hemminga \& Duarte, 2000; Spalding et al., 2003). Indonesia memiliki 13 jenis lamun yang ditemukan di perairan Indonesia (Kiswara, 2009), walaupun sejatinya Indonesia memiliki 15 jenis lamun (Hernawan et al., 2017) dengan tambahan dua jenis Ruppia maritime dan Halophila beccarii yang berupa herbarium di Museum Botani, Bogor.

Secara morfologi, lamun diketahui terbagi atas dua bagian, yaitu lamun bagian atas (above ground) yang meliputi tunas yang ditumbuhi daun, dan lamun bagian bawah (below ground) yang meliputi akar dan rhizoma (Kuo \& den Hartog, 2006). Biomassa lamun bagian atas maupun bawah juga dikenal sebagai kolam karbon. Ekosistem lamun sangat produktif dan menyediakan berbagai jasa ekosistem penting, salah satunya sebagai ekosistem karbon biru (blue carbon) karena mampu menyimpan dan menyerap karbon dalam jumlah besar, sehingga berkontribusi dalam mitigasi dampak perubahan iklim (Duarte \& Chiscano, 1999; Fourqurean et al., 2012). Potensi lamun sebagai karbon biru terbesar terletak pada bagian bawah lamun (below ground), dengan rasio biomassa bagian atas dan bagian bawah pada jenis Zostera capensis yaitu 1:11, sedangkan Halodule wrightii hanya 1:1,13 (Mateo et al., 1997; Boer, 2000). Selain itu, karbon juga tersimpan dalam jumlah besar di dalam sedimen, dimana sumber karbon pada sedimen lamun dapat berupa alloch thonous carbon dan autochthonous carbon. Allochthonous carbon adalah karbon yang berasal dari ekosistem lain dan terdeposit di ekosistem lamun. Hal ini terjadi karena kanopi lamun memiliki fungsi sebagai perangkap partikel di kolom air, sementara akar dan rhizoma berperan mencegah resuspensi, sehingga partikel yang terperangkap akan mengendap dan terakumulasi (Duarte et al., 2013). Autochthonous carbon adalah karbon yang diproduksi oleh lamun (hasil produktivitas primer) dan terdeposit di ekosistem lamun itu sendiri, terutama yang berasal dari rhizoma dan dekomposisi daun. Sebesar $16 \%$ karbon organik yang dihasilkan dari produktivitas primer lamun tersimpan di sedimen, dengan kecepatan akumulasi untuk Posidonia oceanic yaitu $58 \mathrm{gC} / \mathrm{m}^{2} /$ tahun (Mateo et al., 1997; Boer, 2000).

Berdasarkan kompilasi data global, rata-rata stok karbon lamun (biomassa) lamun yaitu $2,52 \mathrm{MgC} / \mathrm{ha}$, terdiri atas $0,77 \mathrm{MgC} /$ ha biomassa bagian atas dan 1,75 $\mathrm{MgC} / \mathrm{ha}$ biomassa bagian bawah (Fourqurean et al., 2012) . Nilai karbon stok global pada ekosistem lamun diperkirakan masih di bawah estimasi (underestimated) karena belum mencakup daerah Indo-Pasifik yang diketahui memiliki luasan lamun terbesar. Hal ini dikarenakan masih terbatasnya data yang tersedia dari kawasan tersebut (Duarte et al., 2013). Beberapa hasil penelitian di Indonesia menunjukkan besarnya karbon stok pada biomassa lamun dan sedimen di beberapa lokasi, antara lain di perairan Teluk Miskam, Tanjung Lesung sebesar $1,32 \mathrm{MgC} / \mathrm{ha}$ atau setara dengan 4,85 $\mathrm{MgCO} 2 \mathrm{e} / \mathrm{ha}$ pada biomassa dan 475,21 MgC/ha atau setara 1.742,43 $\mathrm{MgCO}_{2 \mathrm{e}}$ /ha pada sedimen (Rustam et al., 2014). Teluk Ratatotok memiliki besaran karbon yang tersimpan pada biomassa lamun sebesar 0,57 $\mathrm{MgC} / \mathrm{ha}$ atau setara dengan 2,07 $\mathrm{MgCO}_{2 \mathrm{e}}$ /ha dan pada sedimen sebesar $186,15 \mathrm{MgC} /$ ha atau setara dengan $682,54 \mathrm{MgCO}_{2 \mathrm{e}}$ /ha (Rustam et al., 2014). Nilai stok karbon pada ekosistem lamun bervariasi dari satu lokasi ke lokasi lainnya. Variasi stok karbon lamun tersebut dipengaruhi oleh berbagai faktor, antara lain kompleksitas kanopi lamun, turbiditas, tinggi arus, kedalaman air, tekanan antropogenik (SamperVillarreal et al., 2016; Mazarrasa et al., 2017). Pemahaman mengenai pengaruh faktor-faktor tersebut terhadap stok karbon lamun sangat penting dalam rangka penyusunan strategi pengelolaan ekosistem dan upaya mitigasi perubahan iklim oleh ekosistem lamun. Namun pemahaman tentang faktor tersebut dalam mempengaruhi variasi stok karbon ekosistem lamun masih sangat terbatas.

Kepulauan Seribu merupakan gugusan pulau-pulau kecil dataran berterumbu karang yang secara administrasi merupakan Kabupaten Administrasi Kepulauan Seribu, Propinsi DKI Jakarta, dan terletak di Teluk Jakarta dimana bermuara 13 sungai setelah melewati kota (mega city) Jakarta (Damar, 2003).

Luas total wilayah Kabupaten Administrasi Kepulauan Seribu kurang lebih hampir 11 kali luas daratan Jakarta, yaitu luas daratan mencapai $8,9771 \mathrm{~km}^{2}$ dan luas perairan mencapai $6.997,50 \mathrm{~km}^{2}$. Jumlah keseluruhan pulau yang ada di wilayah Kabupaten Administrasi Kepulauan Seribu mencapai 110 buah (Badan Pusat Statistik, 2018). Berdasarkan karakteristiknya dan kebijakan pembangunan Propinsi DKI Jakarta, pengembangan wilayah Kepulauan Seribu diarahkan untuk beberapa sektor kegiatan seperti meningkatkan kegiatan pariwisata, meningkatkan kualitas kehidupan masyarakat nelayan melalui peningkatan budidaya laut, 
pemanfaatan sumber daya perikanan dengan konservasi ekosistem terumbu karang dan mangrove (Badan Pusat Statistik, 2013). Potensi Kepulauan Seribu yang cukup besar mendorong berbagai pihak untuk melakukan eksploitasi sumber daya yang tersedia. Pembangunan keramba jaring apung, resort, serta aktivitas penangkapan ikan tentunya berdampak terhadap kondisi perairan serta pulau-pulaunya secara umum. Berbagai aktivitas pembangunan di wilayah pesisir Teluk Jakarta dapat berdampak pada kondisi ekosistem dan lingkungan perairan pesisir. Kondisi ini dapat mendegradasi ekosistem lamun sebagai salah satu ekosistem utama di perairan pesisir kepulauan Seribu. Degradasi ekosistem lamun dapat menyebabkan terlepasnya karbon yang tersimpan ke atmosfir, serta mempengaruhi peran ekosistem lamun sebagai produser (sumber makanan) dan area pembesaran maupun pemijahan berbagai jenis biota laut.

Perhitungan stok karbon ekosistem lamun secara menyeluruh di Kepulauan Seribu perlu dilakukan untuk memperoleh informasi terkini potensi carbon sink ekosistem lamun di lokasi tersebut, serta untuk mengkaji dampak tekanan antropogenik terhadap potensi penyimpanan karbon lamun. Tujuan penelitian ini untuk mengetahui variabilitas karbon stok ekosistem lamun di 15 (lima belas) pulau berdasarkan perubahan lingkungan, dengan membagi tiga zona berdasarkan jaraknya dengan daratan utama Jakarta (Teluk Jakarta) serta peranannya sebagai mitigasi perubahan iklim.

\section{BAHAN DAN METODE}

\section{Lokasi Penelitian}

Lokasi penelitian berada di perairan pesisir Kepulauan Seribu yang terbentang antara $5^{\circ} 10^{\prime} 00^{\prime \prime}$ s/d $5^{\circ} 57^{\prime} 00^{\prime \prime}$ Lintang Selatan dan $106^{\circ} 19^{\prime} 30^{\prime \prime} \mathrm{s} / \mathrm{d} 106^{\circ} 44^{\prime} 50^{\prime \prime}$ Bujur Timur. Pengambilan data dilakukan di 15 pulau yang dibagi ke dalam tiga zona berdasarkan kedekatan dengan daratan (gradien jarak), yang merefleksikan perbedaan pengaruh lingkungan. Ketiga zona tersebut antara lain; Zona A yang masih mendapat pengaruh dari daratan Jakarta (meliputi Pulau Lancang Besar, Pulau Lancang Kecil, Pulau Tikus, Pulau Burung, Pulau Kongsi dan Pulau Pari), Zona $\mathrm{C}$ yang tidak mendapat pengaruh dari daratan Jakarta (merupakan Kawasan Taman Nasional Kepulauan Seribu sebagai zona penyangga, meliputi Pulau Pramuka, Pulau Panggang, Pulau Semak Daun, Pulau Kotok Besar dan Pulau Karya), serta Zona B atau tengah merupakan zona antara (peralihan) dari zona A dan $\mathrm{C}$ yang masih mendapat sedikit pengaruh dari daratan Jakarta (meliputi Pulau Payung, Pulau Tidung Besar, Pulau Tidung Kecil dan Pulau Air), seperti yang terlihat pada Gambar 1.

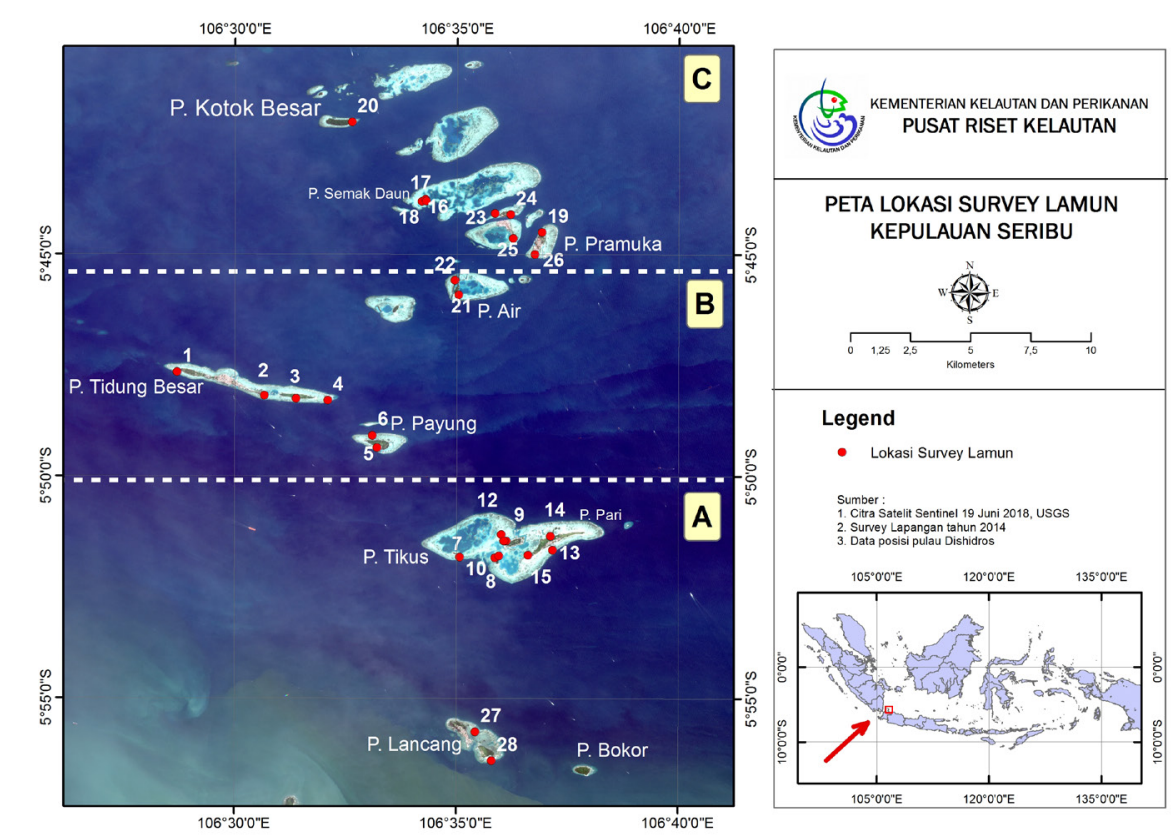

Keterangan:

Zona A: P Lancang Besar; P Lancang Kecil; P Tikus; P Burung; P kongsi; P Pari

Zona B: P Payung; P Tidung Besar; P Tidung Kecil; P Air

Zona C: P Panggang; P Pramuka; P Kotok Besar; P Semak Daun; P Karya

1 (angka): Titik sampling lamun

Gambar 1. Lokasi penelitian di Kepulauan Seribu.

Figure 1. Sudy site at Seribu Archipelago.

Pengaruh Perubahan Lingkungan Terhadap Stok Karbon Pada Ekosistem Lamun Di Pulau-Pulau Kecil, Studi Kasus:

Gugusan Kepulauan Seribu - Agustin Rustam, Yusmiana Puspitaningsih Rahayu, Devi Dwiyanti Suryono,

Hadiwijaya Lesmana Salim, August Daulat, \& Mariska A. Kusumaningtyas 199 


\section{Metode Penelitian}

Pengumpulan data dan informasi dari lapangan menggunakan metode (purposive sampling) sesuai karakteristik objek survei (Effendi, 2003). Spesimen biomassa lamun diambil dengan menggunakan frame/ kuadran berukuran $0,25 \mathrm{~cm} \times 0,25 \mathrm{~cm}$, dan sedimen diambil dengan menggunakan sediment core berbahan baja anti karat.

Spesimen biomassa lamun dibersihkan dari epifit dan substrat yang menempel, kemudian dilanjutkan dengan pemisahaan lamun bagian atas (above ground) berupa tangkai dan daun dengan bagian bawah (below ground) berupa akar dan rhizoma sebelum dilanjutkan dengan penimbangan berat basah dan penyimpanan. Berat kering didapatkan melalui proses pengeringan menggunakan oven pada suhu $60^{\circ} \mathrm{C}$ selama \pm 3 hari. Selanjutnya sampel dihaluskan dan dianalisis menggunakan Carbon Hydrogen Nitrogen Sulfur Analyzer (CHNS analyzer) untuk mendapatkan nilai karbon. Perlakuan yang sama diberikan untuk sampel sedimen yang telah dibagi setiap $5 \mathrm{~cm}$ lapisan kedalaman seperti pada Gambar 2. Analisis nilai karbon dilakukan pada kedalaman permukaan $(0-5$ $\mathrm{cm})$ dan $10-15 \mathrm{~cm}$.

Analisis yang meliputi penutupan jenis lamun (English, Wilkinson \& Baker, 1997); kerapatan lamun (Fachrul, 2008); stok karbon biomassa (Fourqurean et al., 2014) dan stok karbon di sedimen (Sifleet et al., 2011; Kauffman \& Donato, 2012). Luasan lamun didapatkan berdasarkan data sekunder dari Status Lingkungan Hidup Daerah DKI Jakarta tahun 2013 (Pemda DKI, 2013).

\section{HASIL DAN PEMBAHASAN}

\section{Kondisi eksisting ekosistem lamun}

Berdasarkan hasil penelitian di perairan pesisir ke 15 pulau lokasi penelitian, diperoleh sebanyak tujuh jenis lamun dan Cymodoceaceae. Tiga jenis lamun

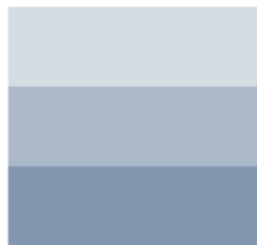

\section{Sampel A: 0 - $5 \mathrm{~cm}$ Sampel B: 5 - $10 \mathrm{~cm}$ Sampel C: $10-15 \mathrm{~cm}$}

Gambar 2. Pembagian lapisan sedimen berdasarkan kedalaman. (Fourqurean et al., 2014)

Figure 2. Sedimentary layer distribution based on depth. (Fourqurean et al., 2014) dari family Hydrocharitaceae, yaitu Enhalus acoroides (Ea), Thalassia hemprichii (Th) dan Halophila ovalis (Ho), sedangkan dari family Cymodoceaceae terbagi ke dalam empat jenis yaitu Cymodocea serrulata (Cs), Cymodocea rotundata $(\mathrm{Cr})$, Halodule uninervis $(\mathrm{Hu})$ dan Syringodium isoetifolium (Si). Jenis-jenis lamun yang ditemukan di 15 lokasi penelitian dapat dilihat dalam Tabel 1.

Jenis lamun yang tersebar merata hampir di seluruh lokasi penelitian adalah jenis lamun berukuran besar (Thalassia hemprichii dan Enhalus acoroides). Kedua jenis lamun tersebut merupakan jenis yang paling melimpah terdapat di perairan Indonesia, dan dapat ditemukan pada habitat dengan berbagai macam substrat dari yang berlumpur darat (terrigenous) hingga sedimen karbonat yang kasar di daerah pasang surut (Tomascik et al., 1997). Kedua jenis lamun tersebut (Th dan Ea) yang masih dapat ditemukan pada dua pulau yang paling dekat dengan daratan utama Jakarta (zona A), yaitu P. Lancang Besar dan P. Lancang Kecil. Kondisi lingkungan di lokasi tersebut masih menunjang pertumbuhan kedua jenis lamun T. hemprichii dan E. acoroides, namun sudah tidak cocok untuk pertumbuhan jenis lamun lain. Masukan sedimen dan jenis substrat menjadi salah satu faktor yang menentukan distribusi lamun. Ramili et al., (2018) menemukan jenis E. acoroides dengan pelepah daun terpanjang pada lokasi dekat ekosistem mangrove yang bersubstrat lumpur, dan di area reklamasi P Hiri, Ternate. Lamun berukuran besar biasanya memiliki sistem perakaran yang kuat yang dapat menjangkau dasar perairan untuk memperkuat tegakan sebagai bentuk strategi adaptasi (Tomascik et al., 1997). Selain itu, di P. Tidung Kecil dan P. Air (zona B) ditemukan hamparan lamun $\mathrm{T}$. hemprichii dan E. acoroides pada kedalaman lebih dari $1 \mathrm{~m}$. Kedua pulau ini tidak berpenduduk namun kedua jenis lamun ini tumbuh subur. Hal ini menunjukkan bahwa kedua jenis ini lebih adaptif dibanding jenis lainnya, sehingga mampu tumbuh di lokasi yang tidak tercemar (oligotrofik/ kurang nutrien) membentuk hamparan maupun lokasi tercemar (eutrotrofik'tinggi nutrien) dalam spot spot kecil yang penuh epifit sebelum hilang digantikan makro alga (Cardoso et al, 2004; Burkholder et al, 2007)

Persentase tutupan total lamun secara keseluruhan di perairan pesisir Kepulauan Seribu selama penelitian berkisar antara $3-100 \%$, dengan persentase tutupan jenis terbesar terukur dari jenis Halodule uninervis $(\mathrm{Hu})$ sebesar $37 \%$, diikuti oleh jenis Thalassia hemprichii (Th) $29 \%$, Syringodium isoetifolium (Si) $18 \%$, dan 
Tabel 1. Jenis-jenis lamun yang ditemukan di 15 lokasi penelitian di perairan pesisir Kepulauan Seribu Table 1. Seagrass species were found in 15 sites in Thousand Islands Archipelago

\begin{tabular}{|c|c|c|c|c|c|c|c|}
\hline & $\begin{array}{l}\text { Enhalus } \\
\text { acoroides }\end{array}$ & $\begin{array}{l}\text { Halophila } \\
\text { ovalis }\end{array}$ & $\begin{array}{l}\text { Thalassia } \\
\text { hemprichii }\end{array}$ & $\begin{array}{l}\text { Cymodocea } \\
\text { serrulata }\end{array}$ & $\begin{array}{l}\text { Cymodocea } \\
\text { rotundata }\end{array}$ & $\begin{array}{l}\text { Syringodium } \\
\text { isoetifolium }\end{array}$ & $\begin{array}{l}\text { Halodule } \\
\text { uninervis }\end{array}$ \\
\hline \multicolumn{8}{|l|}{ Zona A } \\
\hline P Lancang Besar & $\mathrm{X}$ & & $\mathrm{X}$ & & & & \\
\hline P Lancang Kecil & $\mathrm{X}$ & & $\mathrm{X}$ & & & & \\
\hline P Tikus & & & $\mathrm{X}$ & $\mathrm{X}$ & $\mathrm{X}$ & $\mathrm{X}$ & $\mathrm{X}$ \\
\hline P Burung & $\mathrm{X}$ & $\mathrm{X}$ & $\mathrm{X}$ & & & & \\
\hline P Kongsi & $\mathrm{X}$ & $\mathrm{X}$ & $\mathrm{X}$ & & & & \\
\hline P Pari & $X$ & $\mathrm{X}$ & $\mathrm{X}$ & $X$ & $\mathrm{X}$ & $X$ & $\mathrm{X}$ \\
\hline \multicolumn{8}{|l|}{ Zona B } \\
\hline P Payung & $\mathrm{X}$ & $\mathrm{X}$ & $\mathrm{X}$ & & & & \\
\hline P Tidung Besar & $X$ & & $\mathrm{X}$ & $X$ & & & $\mathrm{X}$ \\
\hline P Tidung Kecil & $\mathrm{X}$ & & $X$ & & & & \\
\hline P Air & $\mathrm{X}$ & & $\mathrm{X}$ & & & & \\
\hline \multicolumn{8}{|l|}{ Zona C } \\
\hline P Panggang & $\mathrm{X}$ & $\mathrm{X}$ & $\mathrm{X}$ & $\mathrm{X}$ & $\mathrm{X}$ & $\mathrm{X}$ & $\mathrm{X}$ \\
\hline P Pramuka & $X$ & $\mathrm{X}$ & $\mathrm{X}$ & $\mathrm{X}$ & $\mathrm{X}$ & $X$ & $\mathrm{X}$ \\
\hline P Kotok Besar & & & $\mathrm{X}$ & $\mathrm{X}$ & $\mathrm{X}$ & & $\mathrm{X}$ \\
\hline P Semak Daun & & $\mathrm{X}$ & $\mathrm{X}$ & $\mathrm{X}$ & $\mathrm{X}$ & & $\mathrm{X}$ \\
\hline P Karya & & $\mathrm{X}$ & $\mathrm{X}$ & & & & $\mathrm{X}$ \\
\hline
\end{tabular}

Keterangan: $\mathrm{X}=$ ada

Cymodocea rotundata $(\mathrm{Cr})$ sebesar $10 \%$. Sementara yang terkecil justru dari jenis Enhalus acoroides (Ea) sebesar $2 \%$, meskipun jenis ini ditemukan di hampir semua lokasi penelitian.

Lamun jenis $H$. uninervis umumnya ditemui pada dataran bersubstrat pasir yang mengarah ke laut. Meski demikian, lamun jenis ini diketahui juga dapat hidup pada substrat pasir-berlumpur, hingga karang atol (Den Hartog, 1970; Sidik et al., 1999). Tiga pulau yang padat penduduk (P. Pari, P. Panggang, dan P. Pramuka) ditemukan ketujuh jenis lamun. Di P. Pramuka bahkan kelimpahan jenis $S$. isoetifolium merupakan yang terbesar dibandingkan di pulau lain. Suplai nutrien dari aktifitas antropogenik di pulau, kedalaman air, serta jenis substrat menjadi faktor pendukung pertumbuhan lamun.

\section{Variabilitas stok karbon biomassa lamun}

Hasil perhitungan nilai stok karbon biomassa setiap jenis lamun menunjukkan bahwa jenis lamun dengan ukuran besar memiliki nilai stok yang terbesar. Hal ini mengindikasikan bahwa lamun-lamun yang berukuran besar lebih berpotensi menyimpan dan memanfaatkan karbon, selain karena memiliki biomassa yang besar, juga karena memiliki fungsi ekologis sebagai produser makanan dalam rantai makanan berbasis detritus, dan umumnya lebih tahan terhadap perubahan lingkungan. Lamun berukuran kecil lebih berpotensi sebagai daerah mencari makan dan tempat pembesaran berbagai jenis ikan dengan keberadaan yang lebih dekat dengan ekosistem terumbu karang.

Kemampuan lamun dalam memfiksasi $\mathrm{CO}_{2}$ dalam air yang dimanfaatkan untuk proses fotosintesis akan mengurangi $\mathrm{CO}_{2}$ dalam kolom air dan tersimpan dalam biomassa dan sedimen. Besaran kemampuan lamun dalam menyimpan karbon dalam biomassa berbeda-beda setiap jenisnya. Lamun berukuran besar akan mampu menyimpan karbon dalam biomassa lebih lama dibandingkan dengan yang berukuran kecil, sedangkan epifit yang menempel di daun lamun akan menambah besarnya karbon yang tersimpan (carbon sink).

Berdasarkan Gambar 3, jenis lamun yang tersebar merata hampir di seluruh lokasi penelitian adalah jenis lamun berukuran besar (Thalassia hemprichii dan Enhalus acoroides) dibandingkan dengan lamun berukuran kecil lainnya, namun dengan persentase tutupan yang rendah dan daun lamun yang penuh dengan epifit. Hal ini mengindikasikan adanya perubahan lingkungan yang terjadi di lokasi penelitian sehingga lamun yang berukuran kecil yang 

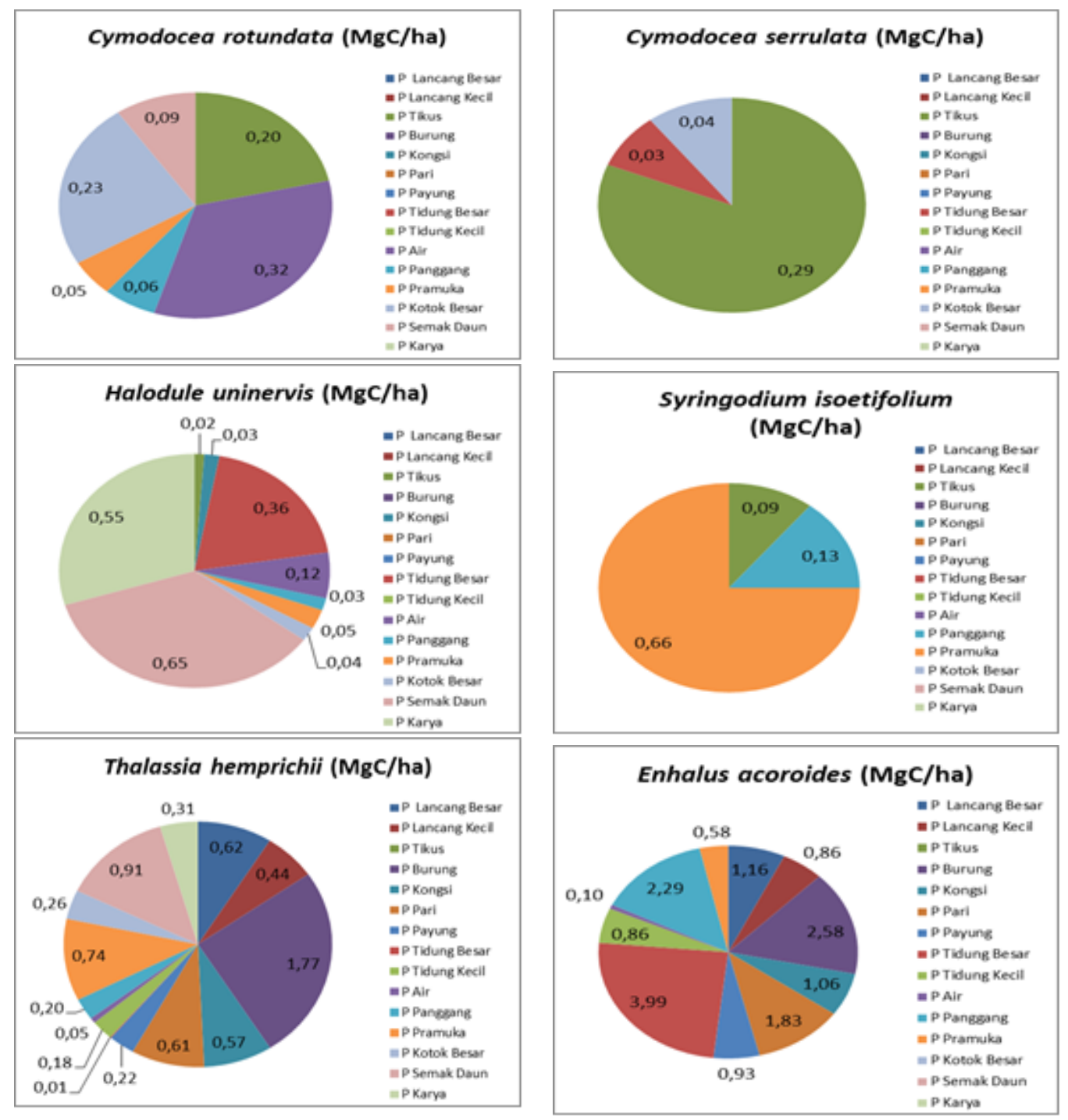

Gambar 3. Stok karbon biomassa lamun berdasarkan jenis (6 jenis ) pada 15 pulau di Kepulauan Seribu. Figure 3. Seagrass biomass carbon stock by species (6 species) on 15 islands in the Seribu Archipelago.

rentan terhadap perubahan lingkungan akan hilang/ terdegradasi, sehingga yang masih bertahan adalah lamun berukuran besar. Penurunan kualitas dan kuantitas lamun akibat degradasi lingkungan selain menghilangkan lamun berukuran kecil, tapi juga dapat berimbas hilangnya lamun berukuran besar digantikan makro alga jika degradasi lingkungan tidak segera diatasi (Cardoso et al, 2004; Burkholder et al, 2007).

Besaran karbon biomassa yang tersimpan pada lamun umumnya lebih besar pada bagian bawah (yang terbenam dalam sedimen) yang terdiri dari rhizoma dan akar lamun (Gambar 4). Terlihat dengan jelas bahwa simpanan karbon biomassa (total atas dan bawah) terbesar terdapat di Pulau Burung, Pulau Panggang dan Pulau Tidung Besar, yaitu dengan ditemukannya persentase penutupan cukup besar (kurang lebih 40 \%) dan lamun berukuran besar yaitu jenis Enhalus acoroides, Thalassia hemprichii dan Cymodocea rotundata di area tersebut.

Stok karbon total di sedimen menunjukkan bahwa umumnya kandungan karbon pada sedimen bertambah tinggi pada kedalaman yang lebih dalam dibandingkan lapisan permukaan. Tingginya nilai karbon yang tersimpan merupakan karbon total yang terdiri atas karbon organik dan karbon anorganik. Lamun merupakan tumbuhan sejati yang telah beradaptasi dengan laut, sehingga sedimen yang menjadi habitat lamun merupakan sedimen asli laut yang umumnya sedimen karbonat. Kepulauan Seribu merupakan gugusan pulau yang terbentuk dari terumbu karang yang tersusun dari sedimen asli laut yang berasal dari pecahan terumbu biota karang, cangkang kerang yang tinggi kandungan karbonatnya atau dikatakan sebagai sedimen karbonat. Tingginya nilai karbon selain berasal dari lamun juga berasal dari pelapukan 


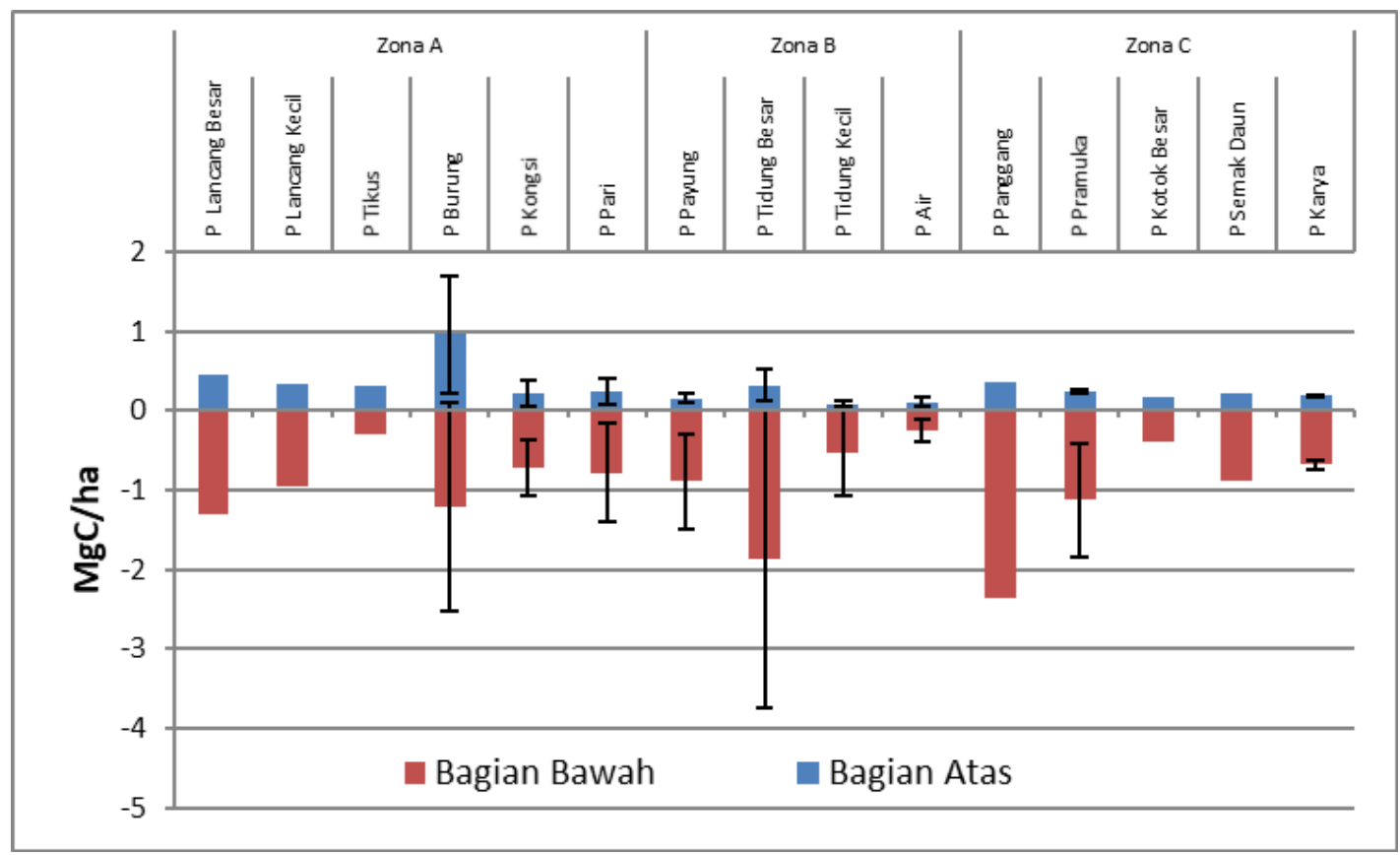

Gambar 4. Stok karbon biomassa Kepulauan Seribu.

Figure 4. Biomass carbon stock in Seribu Archipelago.

cangkang biota laut dan pecahan terumbu karang itu sendiri. Umumnya lamun tumbuh pada sedimen karbonat (Mazarassa et al., 2015).

Berdasarkan pengamatan visual umumnya sedimen di semua lokasi penelitian merupakan sedimen dengan tekstur pasir berwarna putih yang berasal dari pecahan terumbu karang dan cangkang kerang (karbonat), kecuali di lokasi ekosistem lamun yang dominan ditemukan hamparan E. Acoroides, dimana terlihat adanya sedimen berukuran pasir halus dan lumpur berwarna kehitaman seperti di Pulau Pari bagian barat. Berdasarkan zonanya terlihat bahwa zona A umumnya nilai karbon sedimen pada kedalaman $11-15 \mathrm{~cm}$ ada di tiga pulau dari 6 pulau yang ada $(50 \%)$, zona B ada di 3 dari 4 pulau ( $75 \%$ ) dan zona $C$ ada di semua pulau atau sebesar $100 \%$ (Gambar 5). Ini mengindikasikan adanya pengaruh lingkungan terhadap simpanan karbon di sedimen pada ekosistem lamun, untuk lokasi yang dekat dengan daratan adanya tambahan karbon yang berasal dari masukan sungai yang terendapkan di ekosistem lamun Zona A. Semakin jauh jarak dari

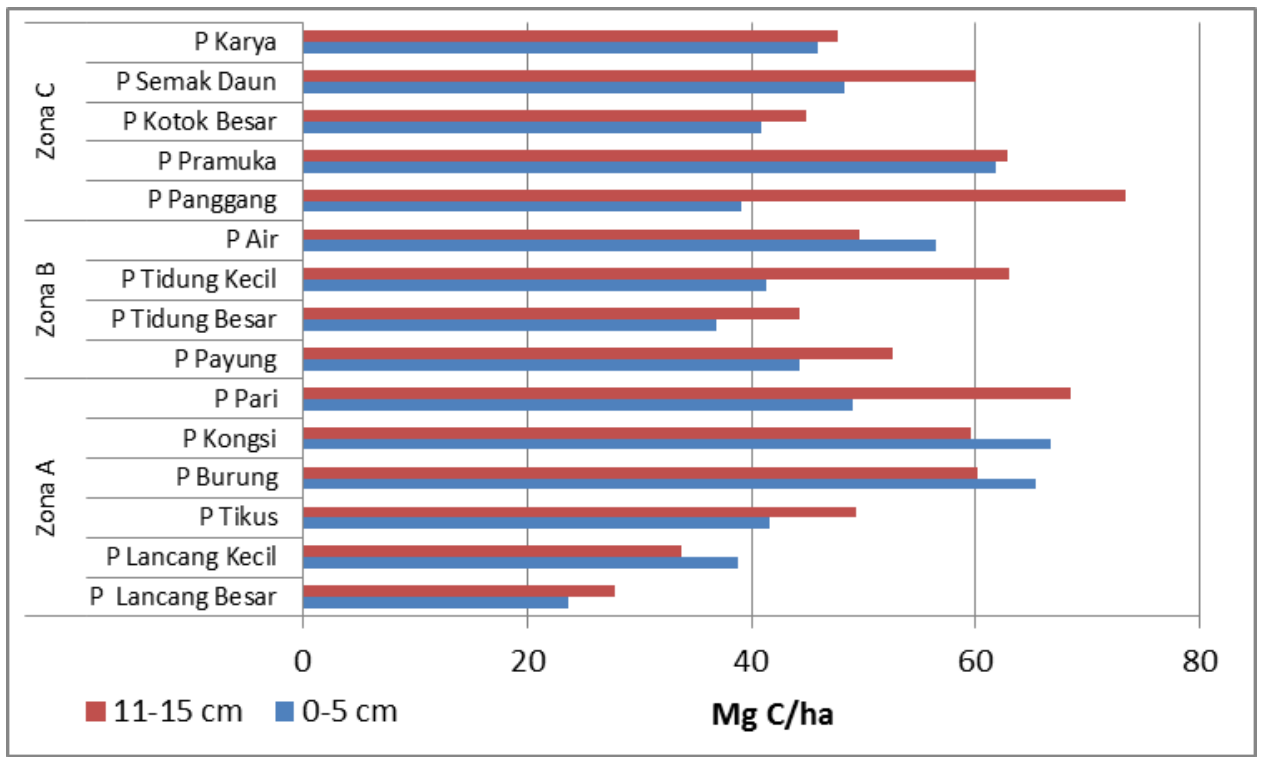

Gambar 5. Stok karbon total di sedimen pada lokasi penelitian.

Figure 5. Sediment total carbon stock at study site. 
Tabel 2. Luas ekosistem lamun dan stok karbon biomassa di Kepulauan Seribu Table 2. The area of seagrass ecosystems and biomass carbon stock in Seribu archipelago

\begin{tabular}{lllll}
\hline & Luas (ha) & $\begin{array}{l}\text { Stok karbon Biomassa } \\
\text { (Mg C/ha) }\end{array}$ & $\begin{array}{l}\text { Stok Karbon } \\
\text { (Mega C) }\end{array}$ & $\begin{array}{l}\text { Stok Karbon } \\
\text { (Giga C) }\end{array}$ \\
\hline Zona A & 3287,69 & 7,800781 & $25.646,55$ & 25,64655 \\
Zona B & 2077,05 & 4,206377 & $8.736,855$ & 8,736855 \\
Zona C & 1261,97 & 6,611835 & $8.343,937$ & 8,343937 \\
\hline
\end{tabular}

daratan, maka kandungan karbon sedimen akan terlihat stabil dengan asumsi berasal dari ekosistem lamun itu sendiri tanpa adanya masukan dari ekosistem lain. Terlepas dari asal usul sedimen, terlihat bahwa pada ekosistem lamun nilai karbon sedimen yang cukup stabil selama penelitian di Kepulauan Seribu dan potensi sedimen yang besar berada pada lapisan lebih dalam (Gambar 5), menunjukkan bahwa ekosistem lamun mampu menahan sedimen sehingga karbon yang ada dalam sedimen terkunci sehingga tidak lepas ke kolom air maupun ke atmosfer.

Luas ekosistem lamun di lokasi penelitian berdasarkan data sekunder untuk zona A seluas 3.297,69 ha, zona B seluas 2.077,05 ha dan zona $C$ seluas 1.261,97 ha (Tabel 2). Berdasarkan luasan lamun serta zonasinya terlihat jelas bahwa lamun berukuran besar memiliki kemampuan bertahan khususnya terhadap pengaruh lingkungan yang berasal dari daratan seperti sedimentasi. Hal ini diperkuat dengan jenis lamun yang ditemukan di zona A terutama pulau yang dekat dengan daratan (P Lancang Besar dan P Lancang Kecil) adalah jenis Enhalus acoroides dan Thalassia hemprichii yang tahan terhadap perubahan lingkungan (Tomascik et al., 1997).

Kerapatan jenis lamun Thalassia hemprichii padat di zona A (Rustam \& Rahayu, 2019) menunjukkan peran dan fungsi ekosistem lamun dalam memerangkap sedimen dari luar ekosistem tinggi yang dibuktikan dengan kandungan karbon sedimen yang tinggi pada lapisan permukaan.

\section{Pengaruh lingkungan terhadap stok karbon biomasa lamun dan potensi mitigasi perubahan iklim}

Stok karbon biomasa lamun per hektar berdasarkan zona dari besar terkecil adalah zona $\mathrm{A}(7,8 \mathrm{MgC} /$ ha), zona C (6,61 MgC/ha) dan zona B (4,21 MgC/ ha). Luasan lamun terluas adalah zona A (3287,69 ha) , kemudian zona B (2077,05 ha) dan terkecil zona C (1261,97 ha). Tinggimya nilai stok karbon biomasa pada zona A selain berdasarkan luasan lamun yang lebih besar juga lamun yang ditemukan 2 jenis lamun berukuran besar yaitu Ea dan Th. Zona $\mathrm{C}$ memiliki nilai stok terendah dibandingkan dua zona lainnya namun

Tabel 3. Analisis deskriptif dan anova nutrien di lokasi penelitian berdasarkan zona

Table 3. Descriptive and anova analysis of nutrient at study site based on zone

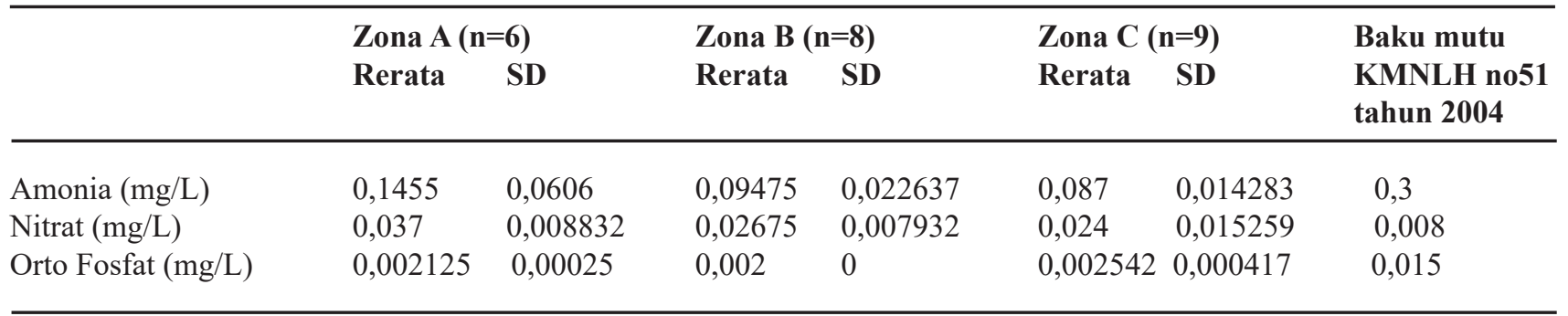

\begin{tabular}{lllllll}
\hline & \multicolumn{3}{c}{ Anova analysis } & \\
\hline Source of Variation & SS & df & MS & F & P-value & F crit \\
\hline Sample & 0,074093 & 2 & 0,037046 & 70,06416 & $2,05 E^{-11}$ & 3,354131 \\
Columns & 0,00395 & 2 & 0,001975 & 3,735561 & 0,036963 & 3,354131 \\
Interaction & 0,004503 & 4 & 0,001126 & 2,129068 & 0,104643 & 2,727765 \\
Within & 0,014276 & 27 & 0,000529 & & & \\
\hline
\end{tabular}

Total

0,096822

35

JURNAL KELAUTAN NASIONAL, Vol 16, No 3, Desember 2021, Hal. 197-208 
dengan keanekaragaman jenis lamun yang tinggi yaitu ditemukan tujuh jenis lamun. Keanekaragaman yang tinggi di zona $\mathrm{C}$ (Tabel 1) mengindikasikan perairan yang bersifat oligotrofik (rendah nutrient) yang masih sesuai untuk pertumbuhan berbagai jenis lamun dari pioneer (berukuran kecil) sampai jenis klimaks (berukuran besar) sehingga lebih mampu beradaptasi.

Secara deskriptif terlihat nilai nutrien tinggi di zona A merupakan zona yang terdekat dengan daratan utama dibandingkan dengan zona $\mathrm{B}$ dan $\mathrm{C}$ Tabel 3). Tingginya nilai nutrien masih mampu dimanfaatkan oleh lamun berukuran besar untuk tumbuh. Namun untuk lamun berukuran kecil atau pioner sudah tidak dapat tumbuh diasumsikan kalah dengan mikro alga yang menutupi daun (epifit) sehingga lamun yang berukuran lebih besar dapat bertahan/adaptasi (resiliensi) adalah lamun berukuran besar (Cardoso et al., 2004; Burkholder, Tomasko and Touchette, 2007; Govers et al., 2014; Lapointe et al., 2020). Selain itu dengan analisis anova sederhana terlihat juga ada perbedaan yang signifikan kandungan nutriet ini berdasarkan zona dengan selang kepercayaan $95 \%$ (Tabel 3).

Potensi ekosistem lamun berdasarkan stok karbon biomasa berdasarkan zona tertinggi pada zona A kemudian zona B dan terakhir zona C. Potensi menyerap $\mathrm{CO}_{2}$ pada zona A sebesar $94.037 \mathrm{Mega} \mathrm{CO}_{2 \mathrm{eq}}$ ; zona B sebesar $32.035 \mathrm{MegaCO}_{2 \mathrm{eq}}$ dan zona $\mathrm{C}$ sebesar $30.594 \mathrm{MegaCO}_{2 \mathrm{e}}$. Potensi mitigasi dalam menyerap $\mathrm{CO}_{2}$ oleh lamun dalam mekanisme fotosintesis dapat hilang jika degradasi lingkungan pengayaan nutrien (eutrofikasi) terus terjadi.

\section{KESIMPULAN DAN SARAN}

Berdasarkan hasil penelitian terlihat bahwa ekosistem lamun terpengaruh oleh perubahan lingkungan khususnya jenis lamun yang berukuran kecil daripada lamun berukuran besar. Dua jenis lamun yaitu Enhalus acoroides dan Thalassia hemprichii mendominasi di perairan pesisir pulau yang berada dalam zona A dengan kemampuannya bertahan dari pengaruh lingkungan dan sedimentasi serta fungsinya dalam memerangkap sedimen dari luar ekosistemnya. Zona B dan C yang berjarak lebih jauh dari daratan dibandingkan zona A memiliki keanekaragaman jenis lamun yang lebih banyak didominasi oleh tipe lamun kecil seperti Halophila ovalis, Cymodocea rotundata, Halodule uninervis dan Syringodium isoetifolium, namun kurang signifikan dalam menyimpan karbon di biomass jika dibandingkan lamun berukuran besar (klimaks).

\section{UCAPAN TERIMA KASIH}

Tulisan ini merupakan sebagian hasil kegiatan penelitian Karbon Biru tahun 2014 di Pusat Penelitian dan Pengembangan Sumberdaya Laut dan Pesisir (P3SDLP), Badan Penelitian dan Pengembangan Kelautan dan Perikanan, Kementerian Kelautan dan Perikanan. Berdasarkan Peraturan Menteri Kelautan dan Perikanan Republik Indonesia Nomor 6/PERMEN-KP/2017 tentang Organisasi dan Tata Kerja Kementerian Kelautan dan Perikanan, institusi ini menjadi Pusat Riset Kelautan, Badan Riset dan Sumberdaya Manusia Kelautan dan Perikanan. Penulis mengucapkan terimakasih pada semua tim Blue Carbon P3SDLP. Agustin Rustam, August Daulat dan Devi Dwiyanti Suryono adalah kontributor utama dalam penulisan artikel ini.

\section{DAFTAR PUSTAKA}

Badan Pusat Statistik (2013) Kabupaten Kepulauan Seribu Dalam Angka 2012. Jakarta.

Badan Pusat Statistik (2018) Kabupaten Kepulauan Seribu Dalam Angka 2018. Jakarta.

Beer, S., Björk, M., Hellblom, F., \& Axelsson, L. (2002). Inorganic Carbon Utilization in Marine Angiosperms (segrasses), Functional Plant Biology, 29(3), 349-354. DOI:10.1071/PP01185

Boer, W. F. de. (2000). Biomass Dynamics of Seagrasses and the Role of Mangrove and Seagrass Vegetation as Different Nutrient Sources for an Intertidal Ecosystem. Aquatic Botany, 66(3), 225-239. doi: 10.1016/S0304-3770(99)00072-8.

Burkholder, J. A. M., Tomasko, D. A., \& Touchette, B. W. (2007). Seagrasses and Eutrophication, Journal of Experimental Marine Biology and Ecology, 350(1-2), 46-72. doi: 10.1016/j. jembe.2007.06.024.

Cardoso, P. G., Miguel, A. P., Lillebø, A. L., Ferreira, S. M. F., Raffaelli, D., \& Marques, J. C. (2004). Dynamic Changes in Seagrass Assemblages Under Eutrophication and Implications for Recovery. Journal of Experimental Marine Biology and Ecology, 302(2). doi: 10.1016/j. jembe.2003.10.014.

Damar, A. (2003). Effects of Enrichment on Nutrient 
Dynamics, Phytoplankton Dynamics and Productivity in Indonesian Tropical Waters: A Comparison Between Jakarta Bay, Lampung Bay and Semangka Bay', MathematischNaturwissenschaftliche Fak., PhD, p. 249.

Duarte, C. M., Kennedy, H., Marba, N., \&Hendriks, I. (2013). Assessing the Capacity of Seagrass Meadows for Carbon Burial: Current Limitations and Future Strategies. Ocean \& Coastal Management, 83, 32-38. doi: 10.1016/j. ocecoaman.2011.09.001.

Duarte, C. M., \& Chiscano, C. L. (1999). Seagrass Biomass and Production: A reassessment, Aquatic Botany, 65(1-4), 159-174. doi: 10.1016/ S0304-3770(99)00038-8.

Duarte, C. M., Sintes, T., \& Marbà, N. (2013). Assessing the $\mathrm{CO}_{2}$ Capture Potential of Seagrass Restoration Projects. Journal of Applied Ecology, 50(6), 1341-1349. doi: 10.1111/13652664.12155 .

Effendi, H. (2003). Telaah Kualitas Air, Bagi Pengelolaan Sumber Daya dan Lingkungan Perairan. Yogyakarta: Kanisius.

English, S., Wilkinson, C., \& Baker, V. (1997). Survey Manual For Tropical Marine Resource. $2^{\text {nd }}$ edn. Townsville: Australia Institute of Marine Science.

Fachrul, M. F. (2008). Metode Sampling Bioekologi. Jakarta.

Fourqurean, J. W., Duarte, C., Kennedy, H., Marba, N., Holmer, M., Mateo, M., Apostolaki, E., Kendrick, G., Krause-Jensen, D., McGlathery, K., \& Serrano, O. (2012). Seagrass Ecosystems as a Globally Significant Carbon Stock. Nature Geoscience. Nature Publishing Group, 5(7), 505-509. doi: 10.1038/ngeo1477.

Gacia, E., Duarte, C. M., \& Middelburg, J. J. (2002). Carbon and Nutrient Deposition in a Mediterranean Seagrass (Posidonia oceanica) Meadow. Limnology and Oceanography, 47(1), 23-32. doi: 10.4319/1o.2002.47.1.0023.

Govers, L. L., Lamers, L. P. M., Bouma, T. J., de Brouwer, J. H. F., \& van-Katwijk, M. M. (2014). Eutrophication Threatens Caribbean Seagrasses -
An Example From Curaçao and Bonaire. Marine Pollution Bulletin, 89(1-2), 481-486. doi: 10.1016/j.marpolbul.2014.09.003.

Hemminga, M. A., \& Duarte, C. M. (2000) Seagrass Ecology. Cambridge University Press. doi: 10.1017/cbo9780511525551.

Hernawan, U. E., Sjafrie, N. D. M., Supriyadi, I. H., Suyarso, Iswari, M. Y., Anggraini, K., \& Rahmat. (2017). Status Padang Lamun Indonesia 2017. Jakarta : Puslit Oseanografi - LIPI.

Howard, J., hoyt, S., Isensee, K., Telszewski, M., \& Pidgeon, E. (eds.). (2014). Coastal Blue Carbon:Methods for assessing carbon stocks and emissions factors in mangroves, tidal salt marshes, and seagrasses. Conservation International, Intergovernmental Oceanographic Commission of UNESCO, International Union for Conservation of Nature. Arlington, Virginia, USA.

Kauffman, J., \& Donato, D. (2012). Protocols for the Measurement, Monitoring and Reporting of Structure, Biomass and Carbon Stocks in Mangrove Forests. Center for International Forestry Research. doi: 10.17528/cifor/003749.

Kiswara, W. (2009). Studi Pendahuluan: Potensi Padang Lamun Sebagai Karbon Rosot dan Penyerapan Karbon di Pulau Pari, Teluk Jakarta. Bogor. Available at: http://file.pksdmo.lipi.go.id/ id018-5fee0-2650_215.pdf.

Kuo, J., \& den-Hartog, C. (2006). Seagrass Morphology, Anatomy, and Ultrastructure, in Seagrasses: Biology, Ecology and Conservation. Springer Netherlands, pp. 51-87. doi: 10.1007/978-14020-2983-7_3.

Lapointe, B. E., Herren, L. W., Brewton, R. A., \& Alderman, P. K. (2020). Nutrient Overenrichment and Light Limitation of Seagrass Communities in the Indian River Lagoon, an Urbanized Subtropical Estuary. Science of the Total Environment, 699, 2020, 134068. doi: 10.1016/j.scitotenv.2019.134068.

Mateo, M. A., Romeo, J., Perez, M., Littler, Mark M., \& Littler, Diane S. (1997). Dynamics of Millenary Organic Deposits Resulting from the Growth of the Mediterranean Seagrass Posidonia oceanica, 
Estuarine, Coastal and Shelf Science, 44(1), 103-110. doi: 10.1006/ecss.1996.0116.

Mazarrasa, I., Marbà, N., Lovelock, C. E., Serrano, O., Lavery, P. S., Fourqurean, J. W., Kennedy, H., Mateo, M. A., Krause-Jensen, D., Steven, A. D. L., \& Duarte, C. M. (2015). Seagrass meadows as a globally significant carbonate reservoir', Biogeosciences, 12, 4993-5003. doi: 10.5194/ bg-12-4993-2015.

Mazarrasa, I., Marbà, N., Garcia-Orellana, J., Masqué, P., Arias-Ortiz, A., \& Duarte, C. M. (2017). Dynamics of Carbon Sources Supporting Burial in Seagrass Sediments Under Increasing Anthropogenic Pressure. Limnology and Oceanography, 62(4), 1451-1465. doi: 10.1002/ lno.10509.

McKenzie, L. J., Finkbeiner, M. A., \& Kirkman, H. (2001). Methods for Mapping Seagrass Distribution. in Short, F. T. and Coles, R. G. (eds) Global Seagrass Research Methods. Amsterdam: Elsevier Science.

Pemda DKI. (2013) Laporan Status Lingkungan Hidup Daerah Provinsi Daerah Khusus Ibukota Jakarta

Ramili, Y., Bengen, D. G., Madduppa, H., \& Kawaroe, M. (2018). Struktur dan Asosiasi Jenis Lamun di Perairan Pulau-pulau Hiri, Ternate, Maitara dan Tidore, Maluku Utara. Jurnal Ilmu dan Teknologi Kelautan Tropis, 10(3), 651-665. doi: 10.29244/jitkt.v10i3.22476.

Rustam, A., Kepel, T. L., Afiati, R. N., Salim, H. L., Kusumaningtyas, M. A., Daulat, A., Mangindaan, P., Sudirman, N., Rahayu, Y. P., Suryono, D. D., \& Hutahaean, A. (2014). Peran Ekosistem Lamun Sebagai Blue Carbon Dalam Mitigasi Perubahan Iklim, Studi Kasus Tanjung Lesung, Banten. Jurnal Segara, 10(July), 107-117.

Rustam, A., \& Rahayu, Y. P. (2019). Status dan Dinamika Ekosistem Lamun Sebagai Feeding Ground Utama di Kepulauan Seribu dalam Husrin, S; Hugroho, D dan Asvaliantina,V (editors). Dinamika dan Tantangan Pengelolaan Ekosistem Pesisir dan Laut di Kepulauan Seribu. IPB Press. ISBN: 978-602-440-000-0
Saunders, M., \& Phinn, S. (2016). Seagrass Morphometrics at Species Level in Moreton Bay, Australia From 2012 to 2013. Scientific Data, 4(1). DOI:10.1038/sdata.2017.60.

Short, F. (2006). Manual for Scientific Monitoring of Seagrass Habitat, SeagrassNet Manual for Scientific Monitoring of Seagrass Habitat, Worldwide edition., (August), 75 pp.

Sifleet, S., Pendleton, L., \& Murray, B. (2011). State of the Science on Coastal Blue Carbon A Summary for Policy Makers. Nicholas Institute Report. NI, (May 2011), 43. doi: 10.1108/13665620210427294.

Spalding, M., Taylor, M., Ravilious, C., Short, F., Green, E. (2003). The Distribution and Status of Seagrasses. in World Atlas of Seagrasses, pp. 5-26.

Tomascik, T., Moosa, M. K., Nontji, A., \& Mah, A. J. (1997). The Ecology of the Indonesian Sea Part Two, The Ecology of the Indonesian Sea. Periplus Editions (HK) Ltd.

Samper-Villarreal, J., Roelfsema, C., Kovacs, E., Adi, N. S., Lyons, M., Mumby, P., Lovelock, C.,

Pengaruh Perubahan Lingkungan Terhadap Stok Karbon Pada Ekosistem Lamun Di Pulau-Pulau Kecil, Studi Kasus: Gugusan Kepulauan Seribu - Agustin Rustam, Yusmiana Puspitaningsih Rahayu, Devi Dwiyanti Suryono, 
